\title{
Analysis and Comparison of "Fragmentation" Social Security Systems in Foreign Countries
}

\author{
Guangzhi Guo \\ Department of Public Security, Zhejiang Police College, Hangzhou, Zhejiang Province, China
}

Keywords: social security; fragmentation; pattern; comparison.

\begin{abstract}
This paper analyzes pension and medical insurance systems of foreign countries, and classifies these social security systems as three patterns according to their "fragmentation" degrees. The first pattern is the integration of urban and rural areas, and the uniform social security system; this pattern is represented by Britain and Switzerland. The second pattern is different systems in urban and rural areas, and establishing rural social security system in specialty; this pattern is represented by Germany and India (medical security system). The third pattern is designing systems according to target crowds; urban and rural systems share some content. This pattern is represented by France, Japan, India (pension system), South Korea, Brazil, Mexico and Spain. On that basis, this paper compares and evaluates the three patterns from three aspects of financial pressure, difficulty of system management and fairness.
\end{abstract}

\section{Introduction}

This paper analyzes foreign social security systems which are mainly composed of pension and medical insurance systems. From a comprehensive perspective, the design of pension system is more complicated than that of medical insurance system. For instance, some countries design pension systems according to different target crowds, but implement unified national medical system. Analyzing from the country level, the majority of countries which implement unified social security system are developed, welfare states; the social security systems of these counties usually have low "fragmentation" degrees. Countries which implement special rural social security systems usually emphasize the importance of agriculture and the proportion of agricultural population. Most countries design security systems according to target crowds, and separate civil servants from other citizens. Table 1-1 shows the basic situation of "fragmentation" social security systems of foreign countries

Table 1-1. The basic situation of "fragmentation" social security systems of foreign countries

\begin{tabular}{|c|c|c|}
\hline pattern & country & basic features \\
\hline $\begin{array}{l}\text { integration of urban and rural areas } \\
\text { and uniform social security system }\end{array}$ & Britain and Switzerland & $\begin{array}{l}\text { The urban and rural social security } \\
\text { systems are not designed to } \\
\text { distinguish urban and rural } \\
\text { residents; their objects are all } \\
\text { citizens. }\end{array}$ \\
\hline $\begin{array}{l}\text { different urban and rural areas, and } \\
\text { establishing rural social security } \\
\text { system in specialty }\end{array}$ & $\begin{array}{l}\text { Germany and India (medical } \\
\text { security system) }\end{array}$ & $\begin{array}{l}\text { The social security system is } \\
\text { designed to distinguish urban and } \\
\text { rural areas, and rural residents have } \\
\text { a special social security system. }\end{array}$ \\
\hline $\begin{array}{l}\text { designing systems according to } \\
\text { target crowd, and the content of } \\
\text { urban and rural systems overlap }\end{array}$ & $\begin{array}{l}\text { France, Japan, India (pension } \\
\text { system), South Korea, Brazil, } \\
\text { Mexico and Spain. }\end{array}$ & $\begin{array}{l}\text { Social security systems are } \\
\text { designed according to target } \\
\text { crowds; it is more complex than } \\
\text { independent urban and rural social } \\
\text { security system. }\end{array}$ \\
\hline
\end{tabular}

\section{Construction Patterns of "Fragmentation" Social Security Systems of Foreign Countries}

The specific situations of foreign social security systems are provided as following from the 
perspective of their "fragmentation" degrees.

\subsection{The integration of urban and rural areas: uniform social security system.}

In this pattern, the urban and rural social security systems are not designed to distinguish urban and rural residents; their objects are all citizens. Britain and Switzerland are typical countries which adopt this system.

As a welfare state, Britain has realized the integration of social security system. Social insurance system is a basic part of the social security system in Britain. Every worker, including employed workers and self employed persons, should pay social insurance premium to the social security department, which is called the National Insurance Contributions, so as to enjoy certain social security rights. National insurance contributions are divided into four categories and five items. Among them, the first category is divided into two items; employees and employers need to pay them respectively. The second category is paid by self employed persons according to wages standards. The third category is voluntary donation; anyone can pay it. The forth category is paid by self employed persons according to profitability levels. [1] It can be seen that British authority does not establish other independent pension insurance system for farmers; the authority takes them as independent workers or non employees, and asks them to pay slightly different premiums. The British medical system is called the National Health Service system. It is mainly provided by the government, and the public health care system covers $99 \%$ of the British population.

Switzerland has a sound social security system. Its pension and medical care systems can be taken out as examples. The Swiss pension system is made up of three pillars. The first pillar is the basic endowment insurance. It is mandatory, and covers the whole population, including self employed and non-professional persons. Their billing criteria and rates are slightly different. The medical insurance system in Switzerland is divided into two parts: statutory (basic) medical insurance and private (supplementary) medical insurance. The former is mandatory, and it covers the whole population.

\subsection{Different systems in urban and rural areas: establishing rural social security system in specialty.}

In the pattern, the social security system is designed to distinguish urban and rural areas, and rural residents have a special social security system. Germany and India (medical security system) are typical countries which adopt this pattern.

Germany: the social security of Germany adheres to the principles of insurance, support and remedy. Social insurance is the core of the social security system. It includes medical insurance, nursing insurance, pension insurance, accident insurance and unemployment insurance. In addition to above five insurances, there is also rural insurance. The rural social security in Germany is a special branch of the whole social security system. It is the combination of all social security measures provided for agricultural workers. In addition, German authority also implements special care and protection insurance for civil servants.

The medical insurance system of India: Indian medical service system is the combination of market and government functions. It has both public health care institutions run by the government and medical services managed by private persons. In the public health service, urban medical system includes two levels: public hospital and city health center, or family welfare center; rural medical service system is a three level health care network, which includes health care stations, primary health care centers and community health care centers.

\subsection{Designing systems according to target crowds; the content of urban and rural systems can be overlapped.}

Most countries adopt this pattern and design social security systems according to target crowds. It is more complex than independent urban and rural social security systems. France, Japan, India (pension system), South Korea, Brazil, Mexico and Spain adopt this pattern.

The French social security system is relatively completed and has wide coverage, but it is not a unified system. The system can be roughly divided to four categories according to the occupations of target crowd: general category (include general staff, students and individual insurers), agriculture 
category (agriculture related workers), salaried category (industrialists, entrepreneurs, businessmen, craftsmen, free occupation persons) and special category (civil servants and employees of state enterprises). Taking the medical insurance as an example, the French health insurance system mainly consists of universal health insurance, mutual medical insurance and commercial medical insurance. Universal health insurance belongs is mandatory social health insurance aims to achieve universal coverage; it includes general and special systems. The general system is also called the common system, covering the majority of population; the special system cover a small part of the population, including agricultural system (agricultural sector employees), freedom occupation persons' system, and other system (public and semi public employees such as civil servants, soldiers, sailors, railway employees, etc.). Different systems have corresponding management institutions.

The social security system of Japan is a complex system. But analyzing from the perspective of pension and medical security, the system is mainly designed according to target crowds. The endowment insurance system mainly includes national pension, welfare pension insurance and mutual aid pension insurance. The objects of national pension are farmers, self-employed persons and other public pension personnel; welfare pension insurance is paid by staff of enterprises; the object of mutual aid pension insurance are government officials, local civil servants, private school faculty and wage earners of forestry and fisheries. The medical insurance system can be divided into two categories. One is paid by industrial workers, staff of government agencies, public employees and their family members. It is called the employee medical insurance. The other kind is paid by farmers, freelancers, etc. It is called the national health insurance.

The old-age security system in India is divided into two parts: the formal sector and the informal sector. The endowment insurance system of formal sector is consisted of civil service pension system, public sector pension system, as well as the bank and insurance company pension plans. The informal sector pension insurance system include Public Provident Fund (aims to provide long-term saving system for people who are not formally covered by the formal pension system), social assistance programs for elderly people from the informal sector, and life insurance industry in rural areas (India government mandates that insurance companies must expand to rural areas). [2]

The social security system of South Korea includes three aspects: social insurance, social assistance and social welfare services. Social insurance is the main component, while pension insurance and medical insurance are main projects which are designed according to different groups. The pension system in South Korea can be divided into two categories: one is the pension system for civil servants, military personnel and private school staff, the other is the national pension for the general staff. South Korean medical insurance is divided into three parts of work unit medical insurance, region medical insurance and medical insurance for civil servants and private school staff (public health insurance). The work unit insurance is paid by work units which have 5 or more employees; employees from other units should pay region insurance [3]. The region medical insurance can be divided into two parts: the rural area and the urban area.

The social security system of Brazil is divided into two levels: the compulsory national social insurance scheme and the auxiliary private insurance plan. In terms of the coverage, the national social insurance can be divided into two categories. One is the "general social security plan"; private employers, employees, domestic helpers, self employed persons and agricultural workers are included in this plan. The other is a social insurance program that covers staff from all levels of government, include federal and state departments. It is also known as the public sector plan [4]. Medical insurance in Brazil is a unified medical system for urban and rural residents, but different groups of people (such as employees, farmers and civil servants) pay slightly different premiums.

Among countries in Latin America, Mexico has an early established and relatively improved social security system. The system is designed mainly according to target crowds. In Mexico, national civil servants, as well as staffs in the army and the state oil companies form a relatively special group, and they have a social security system which is different from the public. It can also be found from the setup of Mexican social security institutions. Firstly, the social insurance commission mainly focuses on workers and staff members of all public and private businesses in urban and rural areas, including employees, owners and their families; all staff from private schools and their families 
are also included in this plan. Secondly, the object of the National Committee to Preserve Social Security and Medicare are staff and their family members of state agencies andpublic schools. Thirdly, a set of social security institutions is established for employees in the army, the state-owned oil companies and other departments. One of the problems of Mexican social security system is that the workers and their dependents are mainly concentrated in cities, and the number of agriculture workers who enjoy the protection is very small. [5]

The social security system of Spain covers almost all members of the society, and emphasizes the balance of rights and obligations. Its public service system is composed of two parts: payment system and the non payment system. One person cannot enjoy security rights provided by the two systems at the same time. The law stipulates that, once a person starts professional activities, it is necessary for the person to join the social security system. It is true for all employed people and freelancers. The Spanish social security system is composed of general social security plan and special social security plan. General social security plan is mainly provided for staffs in manufacture industry, service industry and similar fields; while farmers, seafarers, self-employment persons, family workers, miners, students and civil servants have their own special social security plans. [6]Comparison of the Three Foreign Social Security Patterns

This paper compares the three patterns of foreign social security systems from three perspectives.

\subsection{Financial pressure.}

Generally speaking, western welfare states implement the well-established, unified urban and rural social security system. The guarantee level of this pattern is higher than that of the other two patterns. It also brings high financial pressures. Some countries, such as Britain, are facing the problem of welfare rigidity. Thus, the construction of integrated social security system requires strong financial support from the government. In comparison, financial pressures of the other two patterns are smaller.

\subsection{The difficulty of system management.}

From the perspective of the difficulty of social security management, the most complex pattern, namely the third one, is the most difficult to manage. Different management institutions are usually established to maintain this system. Taking Mexican medical insurance as an example: in order to realize the accessibility of policy, the medical insurance services which cover enterprise employees and their family members are provided by the social insurance agency; unemployment rural and urban residents can enjoy the health care services provided by the Ministry of Health; poor people who do not have any medical insurance are offered with "citizen medical insurance". [7] By comparison, the management of the first pattern, urban and rural integration is relatively less difficult. The management difficulty of the second pattern lies between the first and third patterns.

\subsection{Fairness.}

From the perspective of fairness, the integrated social security system implemented by welfare states is fairer, because it covers almost all residents, and has complete legal system which can guarantee people's basic rights as insurants. In the early stage of social security system development, the second and third patterns are usually adopted. The overall fairness of these patterns may be lowered, since different groups have different system designs, and some people are not covered by the system. Through the comparison of these three patterns, it can be found that the first one pays more attention to the fairness of security treatment, while the latter two patterns pay more attention on the fairness of coverage, or the accessibility of policies. Therefore, with the development of society and the increasing attention on social equality values, the development direction of social security system is bound to be the integration of urban and rural areas.

\section{References}

[1] C.Y. Sun, British social security system and enlightenment to our country, J. Tianjin Social Insurance. 3 (2008).

[2] L. Zhang, Overview of Indian social security system, J. South Asian Studies Quarterly. 2 (2006). 
[3] B.R. Zhang, H.Z. Zhang, Analysis of social security system in South Korea, J. Population Journal. 4 (2000).

[4] L.Q. Fang, Analysis of Brazilian social security system reform since 1990s, J. Journal of Latin American Studies. 2 (2009).

[5] S.C. Xu, Social security system reform in Mexico, J. Journal of Latin American Studies. 4 (1997).

[6] Y. Liu, Spanish social security system: the balance of rights and obligations, J. China State Finance. 9 (2008).

[7] Z.P. Zhu. Brief analysis of Mexican social security system, J. Tianjin Social Insurance. 3 (2009).

[8] L.F. Yang, Evaluation and revelation of German social security system, J. Reformation \& Strategy. 6 (2007).

[9] H. Li, A survey of the social insurance system in Germany, as well as its crisis and reform, J. Technical Economy. 5 (2007).

[10] D. Ma, R. Ren, Brazilian medical security system, J. Medicine and Philosophy, Humanities and Social Science Edition. 10 (2007).

[11] X. Liu, An analysis of British pension insurance system, J. Heilongjiang Foreign Economic Relations and Trade. 2 (2008).

[12] B.L. Zeng, Characteristics and enlightenment of Austrian social security system, J. The Journal of Yunnan Administration College. 1 (2001).

[13] L.R. Li, Swiss social security system, J. China Insurance, 1997 (10): 43.

[14] Y. Zhang, A brief analysis on enlightenment of Chilean social security reform on China, J. Journal of Shanxi University of Finance and Economics, J. 2 (2009).

[15] X.W. Li, The development and enlightenment of retirement pension system in Japan, J. Contemporary Economy of Japan. 4 (2002).

[16] C. Ren, Indian medical security system, J. The Contemporary World. 7 (2006).

[17] International Cooperation Department of the Ministry of Human Resources and Social Security, An overview of French medical insurance system, J. China Labor Security. 5 (2009).

[18] M. Chen, J. Yu, Polish social security system, J. Global Scientific and Technological Outlook. 5 (2002).

[19] X.Y. Zeng, American social security system and enlightenment. J. Jiangsu Social Sciences. 6 (2006). 